In cooperation with the Lac Courte Oreilles Band of Lake Superior Chippewa

Simulation of Contributing Areas and Surface-Water Leakage to Potential Replacement Wells Near the Community of New Post, Sawyer County, Wisconsin, by Means of a Two-Dimensional Ground-Water-Flow Model

Open-File Report 2008-1133 



\section{Simulation of Contributing Areas and Surface-Water Leakage to Potential Replacement Wells Near the Community of New Post, Sawyer County, Wisconsin, by Means of a Two-Dimensional Ground- Water-Flow Model}

By Paul F. Juckem and Randall J. Hunt

In cooperation with the Lac Courte Oreilles Band of Lake Superior Chippewa

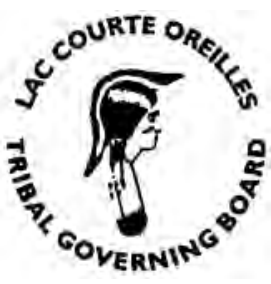

Open-File Report 2008-1133 


\section{U.S. Department of the Interior DIRK KEMPTHORNE, Secretary}

\section{U.S. Geological Survey \\ Mark D. Myers, Director}

\section{U.S. Geological Survey, Reston, Virginia: 2008}

For product and ordering information:

World Wide Web: http://www.usgs.gov/pubprod

Telephone: 1-888-ASK-USGS

For more information on the USGS - the Federal source for science about the Earth, its natural and living resources, natural hazards, and the environment:

World Wide Web: http://www.usgs.gov

Telephone: 1-888-ASK-USGS

Any use of trade, product, or firm names is for descriptive purposes only and does not imply endorsement by the U.S. Government.

Although this report is in the public domain, permission must be secured from the individual copyright owners to reproduce any copyrighted materials contained within this report.

Suggested citation:

Juckem, P.F., and Hunt, R.J., 2008, Simulation of contributing areas and surface-water leakage to potential replacement wells near the community of New Post, Sawyer County, Wisconsin, by means of a two-dimensional groundwater-flow model: U.S. Geological Survey Open-File Report 2008-1133, 12 p. 


\section{Contents}

Abstract
Introduction.
Purpose and Scope
Physical Setting.
Data Sources
Methodsumptions and Limitations
Refinement of the Model to Simulate Possible Replacement Wells
Results of Simulating Potential Replacement Wells
Siscussion
References Cited.

\section{Figures}

1-6. Maps showing simulated contributing areas for potential replacement wells pumping 30,000 gallons per day at specified locations and resistances to vertical flow along the Chippewa Flowage:

1. Well at borehole $\mathrm{BH}-2$, low resistance $(0.005$ day) (scenario 1$)$................................5

2. Well at borehole $\mathrm{BH}-2$, high resistance $(5$ days) (scenario 2$)$..................................

3. Replacement well $B$, low resistance (0.005 day) (scenario 3).................................

4. Replacement well $B$, high resistance (5 days) (scenario 4)...................................

5. Replacement well C, low resistance $(0.005$ day) (scenario 5$)$..................................

6. Replacement well C, high resistance (5 days)(scenario 6)...................................10 


\section{Conversion Factors}

\begin{tabular}{lcl}
\hline Multiply & By & To obtain \\
\hline foot $(\mathrm{ft})$ & Length & \\
\hline & 0.3048 & meter $(\mathrm{m})$ \\
\hline gallon per day $(\mathrm{gal} / \mathrm{d})$ & Rate & \\
\hline & 0.003785 & cubic meter per day $\left(\mathrm{m}^{3} / \mathrm{d}\right)$ \\
\hline foot per day $(\mathrm{ft} / \mathrm{d})$ & Hydraulic conductivity* & \\
\hline
\end{tabular}

Vertical coordinate information is referenced to the North American Vertical Datum of 1988 (NAVD 88).

Elevation, as used in this report, refers to distance above the vertical datum.

*Hydraulic conductivity: The standard unit for hydraulic conductivity is cubic foot per day per square foot of aquifer cross-sectional area $\left(\mathrm{ft}^{3} / \mathrm{d} / \mathrm{ft}^{2}\right)$. In this report, the mathematically reduced form, foot per day $(\mathrm{ft} / \mathrm{d})$, is used for convenience. 


\title{
Simulation of Contributing Areas and Surface-Water Leakage to Potential Replacement Wells Near the Community of New Post, Sawyer County, Wisconsin, by Means of a Two-Dimensional Ground-Water-Flow Model
}

\author{
By Paul F. Juckem and Randall J. Hunt
}

\begin{abstract}
A two-dimensional, steady-state ground-water-flow model of the shallow ground-water-flow system near the community of New Post, Sawyer County, Wis., was refined from an existing model of the area. Hydraulic-conductivity and recharge values were not changed from the existing model for the scenario simulations described in this report. Rather, the model was refined by adding detail along the Chippewa Flowage and then was used to simulate contributing areas for three potential replacement wells pumping 30,000 gallons per day. The model also was used to simulate potential surface-water leakage out of the Chippewa Flowage captured by replacement-well pumping. A range in resistance to vertical ground-water flow was simulated along the Chippewa Flowage for each potential replacement-well location to bound the potential effects of representing three-dimensional flow with a two-dimensional model. Results indicate that pumping from a replacement well sited about 130 feet from the Chippewa Flowage could capture as much as 39 percent of the total pumping from the flowage. Pumping from either of two potential replacement wells sited at least 400 feet from the Chippewa Flowage did not induce surface-water leakage out of the flowage regardless of the resistance applied along the flowage for simulations described in this report.
\end{abstract}

\section{Introduction}

The community of New Post, Wis., is interested in drilling a new water-supply well to replace two existing wells. The Lac Courte Oreilles Band of Lake Superior Chippewa (LCO) Public Works Department and the Indian Health Service (IHS) are concerned about the potential for a new well to capture surface water from the Chippewa Flowage. A previous study by the USGS (Juckem and Hunt, 2007), in cooperation with the LCO, evaluated the shallow ground-water-flow system near Grindstone Creek and the community of New Post on the LCO reservation. Simulations with the analytic element model developed by Juckem and Hunt (2007) were previously used to evaluate contributing areas (the land-surface area that contributes ground-water recharge to the well) and the potential to capture surface water for the existing wells and two potential replacement wells. Additional simulations were recently requested by LCO and IHS to evaluate contributing areas and surface-water leakage for a higher pumping rate at one of the previously evaluated potential replacement wells and at two additional well locations.

\section{Purpose and Scope}

This report describes the refinement and results of twodimensional, steady-state, ground-water-flow modeling of the shallow hydrologic system near the community of New Post, Sawyer County, Wis. The purpose of these simulations was to estimate the ground-water contributing areas for three potential replacement wells and evaluate the potential of the wells to capture surface-water leakage out of the Chippewa Flowage. The model theory, construction, and calibration of the underlying regional model are fully described by Juckem and Hunt (2007). No additional ground-water-level or streamflow data have been collected in the area of interest, and the underlying model has not been recalibrated.

\section{Physical Setting}

The regional and local settings are described by Juckem and Hunt (2007); important features of the local setting are briefly described here. The community of New Post is in central Sawyer County along the southern shores of the Chippewa Flowage. The ground-water-flow system near New Post is bounded by the Chippewa Flowage to the north and a crystalline bedrock mound buried by glacial sand and gravel to the south. Boreholes indicate an increase in aquifer thickness from 
the crystalline mound northward toward the Chippewa Flowage. The sand and gravel aquifer has a relatively high horizontal hydraulic conductivity (Tyrolt, 2006; Juckem and Hunt, 2007) and no laterally extensive confining beds.

\section{Data Sources}

No new data were incorporated into this effort; data sources used to refine the model were the same as those used in the original study by Juckem and Hunt (2007).

\section{Assumptions and Limitations}

Given the relatively coarse nature of the unconsolidated sediments, relatively high net annual precipitation, and ground-water levels being near the flowage stage, the groundwater and surface-water systems were assumed to have a close hydrologic connection in the modeled area. Therefore, elevations of surface-water features were assumed to be representative of the ground-water system. A two-dimensional model was assumed to be appropriate for the larger model domain because the ground-water-flow system is thin and areally extensive. However, because two-dimensional models may not accurately represent the ground-water-flow system within two to three aquifer thicknesses of a surface-water feature (Haitjema, 1995, 2006; Hunt and others, 2003), simulated ground-water gradients near surface-water features and the amount of ground-water/surface-water exchange should be considered only approximate. In addition, all replacement wells were assumed to be open to the full saturated thickness of the aquifer. Finally, steady-state simulations were also assumed appropriate for this study. Steady-state simulations can be expected to result in an estimate of the higher range of system response to a hydrologic stress because they are not mitigated by ground-water release from storage.

\section{Methods}

An analytic element ground-water-flow model, developed with the computer program GFLOW (Haitjema, 1995) was used to simulate the ground-water system and its interaction with surface-water features. A complete description of analytic elements is beyond the scope of this report, but a brief description follows. (Hunt (2006) gives a review of applications of the analytic element method, and Haitjema (1995) discusses the underlying concepts and mathematics of the method in detail.)

An infinite aquifer is assumed in analytic element modeling. To construct an analytic element model, features important for controlling ground-water flow (for example, wells and surface-water features) are entered as mathematical elements or strings of elements. The amount of detail specified for the features depends on distance from the area of interest. Each element is represented by an analytic solution. The effects of these individual solutions are added together to form a solution for any location in the simulated ground-water-flow system. In the GFLOW code used here, the analytic elements are two dimensional and are used only to simulate steady-state conditions (water levels that do not vary with time). The analytic element method and comparisons of analytic element to finitedifference numerical model techniques have been discussed by others (Haitjema, 1995; Hunt and Krohelski, 1996; Hunt and others, 1998, 2003).

Hydraulic conductivity and recharge values calibrated by Juckem and Hunt (2007) were not changed for the simulations described in this report. Streambed resistance for the Chippewa Flowage was varied over a range of reasonable values to approximate a range in resistance to vertical ground-water flow, but streambed resistance for all other surface-water features was set to the original values of Juckem and Hunt (2007). Likewise, the width parameter (Haitjema, 1995, 2005; Hunt and others, 2003) was computed automatically by the GFLOW model for the Chippewa Flowage based on the local transmissivity and resistance, but the values of Juckem and Hunt (2007) were used for all other surface-water features. A range of values for streambed resistance for the Chippewa Flowage was used to simulate a range of possible surface-water capture for the simulated potential replacement wells.

\section{Conceptual Model}

A conceptual model is a simplification of the hydrologic system into important component parts, and it forms the framework for computer simulations. This simplification is necessary because inclusion of all of the hydrogeologic complexities into a model is not feasible. Steps in the development of the conceptual model include (1) characterization of the aquifer(s), (2) identification of sources and sinks of water, and (3) identification and delineation of hydrologic boundaries in the area of interest. The conceptual model of the hydrologic system near the community of New Post was described by Juckem and Hunt (2007); it has been refined for the scenarios described in this report, with the important features described below.

The aquifer consists of glacial sediments that were deposited directly on top of crystalline rocks in the New Post area. Thickness of the glacial sediments is varied and related in part to the elevation of the underlying crystalline bedrock. Bedrock is within $25 \mathrm{ft}$ of the land surface along the southern edge of New Post, where it forms a major hydraulic boundary for the glacial aquifer, but is more than $100 \mathrm{ft}$ below land surface beneath most of New Post and the area north of the community. The topography of the crystalline bedrock in the immediate vicinity of New Post is constrained by data from three geologic borings drilled for the original study (Juckem and Hunt, 2007). However, the crystalline-bedrock elevation is only approximately known at distance from these boreholes. 
The distant hydraulic boundaries for the system are directly derived from the regional model of Juckem and Hunt (2007). However, the local hydraulic boundaries are important for determining well capture zones because capture zones in this area depend on the distribution of flow between two competing discharge points or "sinks" for the ground-water system. The first possible sink is the regionally important Chippewa Flowage. The second is the potential replacement well. Where simulated pumping reverses the vertical gradient (lowers ground-water heads below the Chippewa Flowage to a level below the lake stage), surface water from the flowage can enter the aquifer. Thus, the conceptual model includes local infiltration of precipitation that recharges the ground-water system and potential local surface-water leakage from the Chippewa Flowage. The recharge and potential surface-water leakage is in turn captured by either the Chippewa Flowage or the replacement well with simulated pumping.

\section{Refinement of the Model to Simulate Possible Replacement Wells}

Linesinks and inhomogeneities of the original regional ground-water-flow model of Juckem and Hunt (2007) were locally refined to improve simulation of local-scale groundwater/surface-water interaction along the Chippewa Flowage near New Post. For the refined model simulations, properties of the regional model remained unchanged, except the streambed resistance and width parameters for the Chippewa Flowage. Streambed resistance is defined as the thickness of sediment between a surface-water body and the aquifer, divided by the vertical hydraulic conductivity of the sediment; in its mathematically reduced form, streambed resistance is expressed in units of days. For example, a model value of 0.5 days used to simulate streambed sediments (Juckem and Hunt, 2007) corresponds to a 1 -ft sediment thickness and a vertical hydraulic conductivity of $2 \mathrm{ft} / \mathrm{d}$. Reservoirs and flowages, which are the result of manmade flooding, are expected to have low resistance because they lack much of the fine-grained sediment that underlies lakes created by sediment-laden glaciers (Graczyk and others, 2003).

Two streambed resistances were simulated for each of three potential replacement wells pumping at 30,000 gal/d, for a total of six scenarios. The first approach represented low streambed resistance to vertical ground-water flow along the Chippewa Flowage. Assumptions for this approach are minimal sediment thickness $(0.1 \mathrm{ft})$ between the Chippewa Flowage and the aquifer, and an estimated horizontal to vertical hydraulic conductivity ratio of 3:1 (Kenoyer, 1988). This ratio was multiplied by the calibrated horizontal hydraulic conductivity of the regional model (58.2 ft/d; Juckem and Hunt, 2007) to compute a vertical hydraulic conductivity of $19.4 \mathrm{ft} / \mathrm{d}$ and a resistance of 0.005 day along the Chippewa Flowage. This low vertical resistance represents an end extreme for which there is a high potential for surface-water leakage into the aquifer due to pumping.

The second approach incorporated high streambed resistance to vertical ground-water flow by applying the same vertical hydraulic conductivity $(19.4 \mathrm{ft} / \mathrm{d})$ across $100 \mathrm{ft}$ of aquifer material. The computed resistance of 5.2 days approximates the thickness of aquifer material between the Chippewa Flowage (1,311.77 ft elevation) and a well with a 20 -ft screen placed at the bottom of the aquifer (approximately 1,192 ft elevation at borehole BH-2; Juckem and Hunt, 2007). This higher vertical resistance represents an end extreme that is more than two orders of magnitude larger than the computed resistance to vertical flow in a homogeneous and isotropic aquifer due to representing a three-dimensional flow system with a twodimensional model (equation 38 of Haitjema, 2005). Thus, there is relatively less potential for surface-water leakage into the aquifer due to pumping for simulations incorporating this higher resistance.

The refined model was used to simulate contributing areas and ground-water/surface-water interactions for three replacement wells pumping 30,000 gal/d. Two end extremes representing a reasonable range in resistance to vertical ground-water flow were simulated for each pumping well scenario. In all, a total of six simulations of the refined model were done. Each simulation included one of three possible replacement wells and one of two values of streambed resistance along the Chippewa Flowage. The contributing area for each potential replacement well was delineated by backward particle tracking to the water table for 100 hypothetical particles of water placed at the bottom of the well. Surface-water leakage into the aquifer from the Chippewa Flowage also was quantified for scenarios in which leakage occurred.

\section{Results of Simulating Potential Replacement Wells}

Scenario 1 (fig. 1) simulated pumping from a well at borehole BH-2 and low resistance ( 0.005 day) to vertical flow along the Chippewa Flowage. The contributing area extended from the crystalline bedrock mound at the southern boundary of the local aquifer to the Chippewa Flowage at the northern boundary. Surface-water leakage from the Chippewa Flowage accounted for 39 percent $(11,800 \mathrm{gal} / \mathrm{d})$ of the water captured by the well. Because of the low resistance along the Chippewa Flowage and the two-dimensional formulation of ground-water flow in the model, this scenario represents an upper bound to the expected amount of surface-water leakage for pumping $30,000 \mathrm{gal} / \mathrm{d}$ from a well near BH-2.

Scenario 2 (fig. 2) simulated pumping from a well at borehole $\mathrm{BH}-2$ and high resistance ( 5 days) associated with $100 \mathrm{ft}$ of aquifer material below the Chippewa Flowage. The contributing area extended from the crystalline bedrock mound to the Chippewa Flowage, but also included an area north of the flowage. Water captured from the north side of the 
Chippewa Flowage offset some of the surface-water leakage captured by the well in scenario 1 . Surface-water leakage from the Chippewa Flowage accounted for about 1 percent $(340$ $\mathrm{gal} / \mathrm{d}$ ) of the water captured by the well.

Scenarios 3 and 4 (figs. 3 and 4) simulated pumping from potential replacement well B (lat $45^{\circ} 53^{\prime} 46.40^{\prime \prime} \mathrm{N}$., long $91^{\circ} 11^{\prime} 7.45^{\prime \prime} \mathrm{W}$.), with low and high resistance along the Chippewa Flowage, respectively. Both scenarios produced a contributing area that extended from the crystalline bedrock mound to within about $100 \mathrm{ft}$ of the Chippewa Flowage shoreline, and neither induced surface-water leakage from the Chippewa Flowage.

Scenarios 5 and 6 (figs. 5 and 6) simulated pumping from potential replacement well C (lat 45 $53^{\prime} 42.44^{\prime \prime} \mathrm{N}$., long $91^{\circ} 11^{\prime} 31.13^{\prime \prime W}$.), and low and high resistance along the Chippewa Flowage, respectively. The contributing area for both scenarios extended from the crystalline bedrock mound to within a few hundred feet of a small bay connected to the Chippewa Flowage. Similar to scenarios 3 and 4, no surfacewater leakage was simulated for scenarios 5 or 6 .

\section{Discussion}

Pumping from an aquifer can induce downward vertical hydraulic gradients between a nearby surface-water feature and the well screen. The magnitude of ground-water/surfacewater interaction depends in part upon the resistance to vertical flow associated with the aquifer material and any intervening confining units, as well as the horizontal distance between the well and the surface-water feature. Haitjema (2006) demonstrated that resistance to vertical flow near a surfacewater feature is important within a distance equal to twice the saturated thickness times the square root of the horizontal to vertical hydraulic conductivity ratio of the aquifer. Given the assumptions for simulations described in this report (a 3:1 hydraulic conductivity ratio and $120 \mathrm{ft}$ of saturated aquifer thickness), the vertical component of flow can be considered important within about $415 \mathrm{ft}$ of the Chippewa Flowage. In other words, the two-dimensional model may not accurately approximate three-dimensional flow within about $415 \mathrm{ft}$, which can have a minor effect on heads, leakage, and contributing areas within this distance (Haitjema, 2006). Borehole $\mathrm{BH}-2$ is approximately $130 \mathrm{ft}$ from the flowage. Potential replacement well B is approximately $530 \mathrm{ft}$ from the flowage, where as potential replacement well $\mathrm{C}$ is approximately $400 \mathrm{ft}$ from the flowage.

As described above, simulations of pumping from a potential replacement well at $\mathrm{BH}-2$ are within the distance to a surface-water feature for which vertical flow is important. Potential replacement wells $\mathrm{B}$ and $\mathrm{C}$ are near or outside the distance for which vertical flow is expected to be important. Although limitations associated with the two-dimensional model may be present in scenarios 1 and 2, the simulated range in resistance values was expected to provide a reasonable range of surface-water leakage from the Chippewa Flowage under steady-state conditions. Moreover, the similarity of results for simulations with low and high resistance provides additional confidence that pumping 30,000 gal/d from potential replacement wells $\mathrm{B}$ and $\mathrm{C}$ would induce little, if any, surface-water leakage into the aquifer.

Scenario testing with a three-dimensional model calibrated to vertical water-level data could further decrease uncertainty in the results described in this report. Moreover, transient simulations incorporating fluctuations in the water level of the Chippewa Flowage would provide insight into the natural exchange of water between the flowage and the aquifer, as well as help constrain estimates of resistance of the Chippewa Flowage streambed. Additional transient water-level collection in vertically nested monitoring wells in the immediate vicinity of the area of interest would improve the ability to estimate values of vertical hydraulic conductivity in the aquifer, which is important for simulating contributing areas and ground-water/surface-water interaction. 




Figure 1. Simulated contributing area for a potential replacement well at borehole BH-2 pumping 30,000 gallons per day, and low resistance ( 0.005 day) to vertical flow along the Chippewa Flowage (scenario 1). 


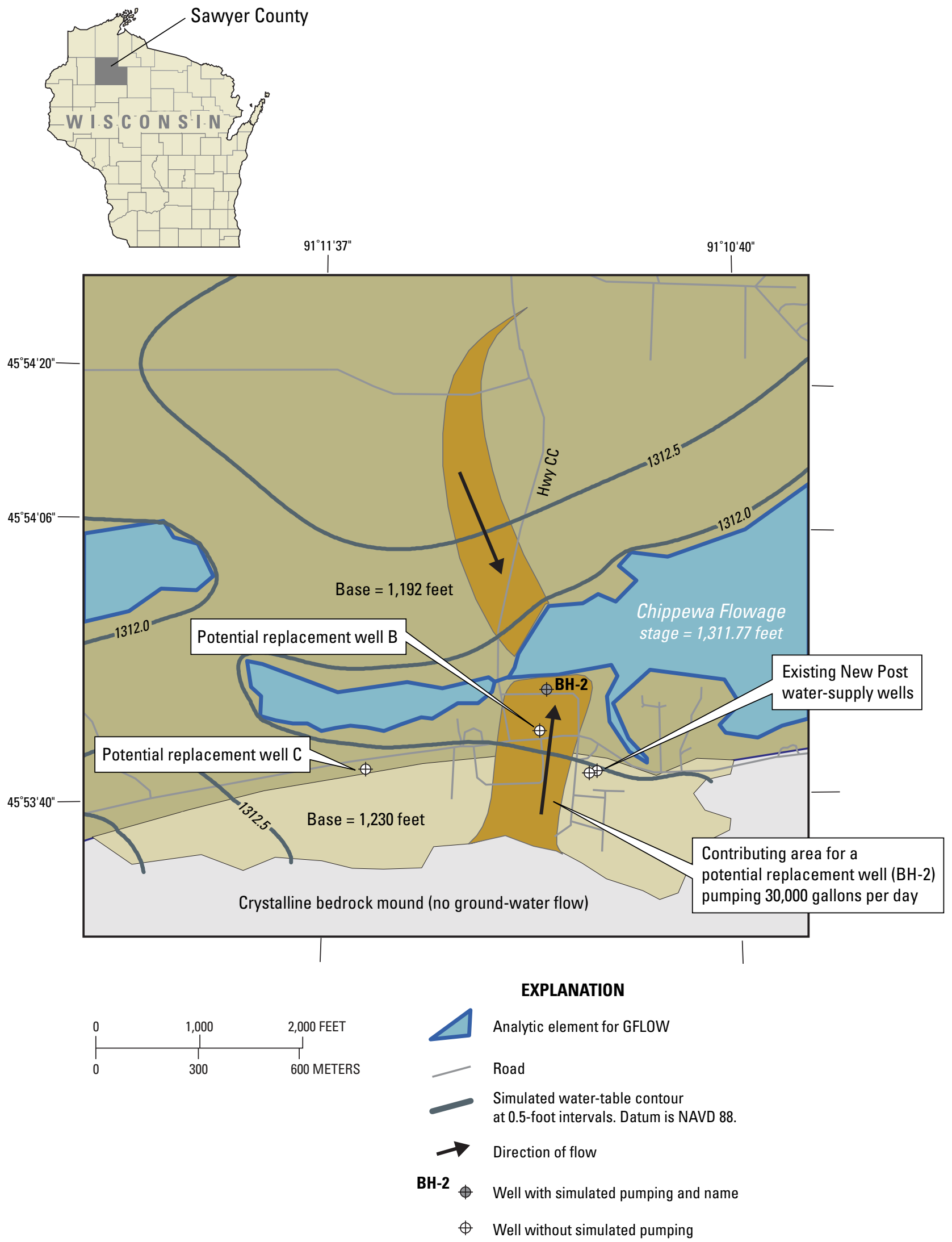

Figure 2. Simulated contributing area for a potential replacement well at borehole BH-2 pumping 30,000 gallons per day, and high resistance (5 days) to vertical flow along the Chippewa Flowage (scenario 2). 


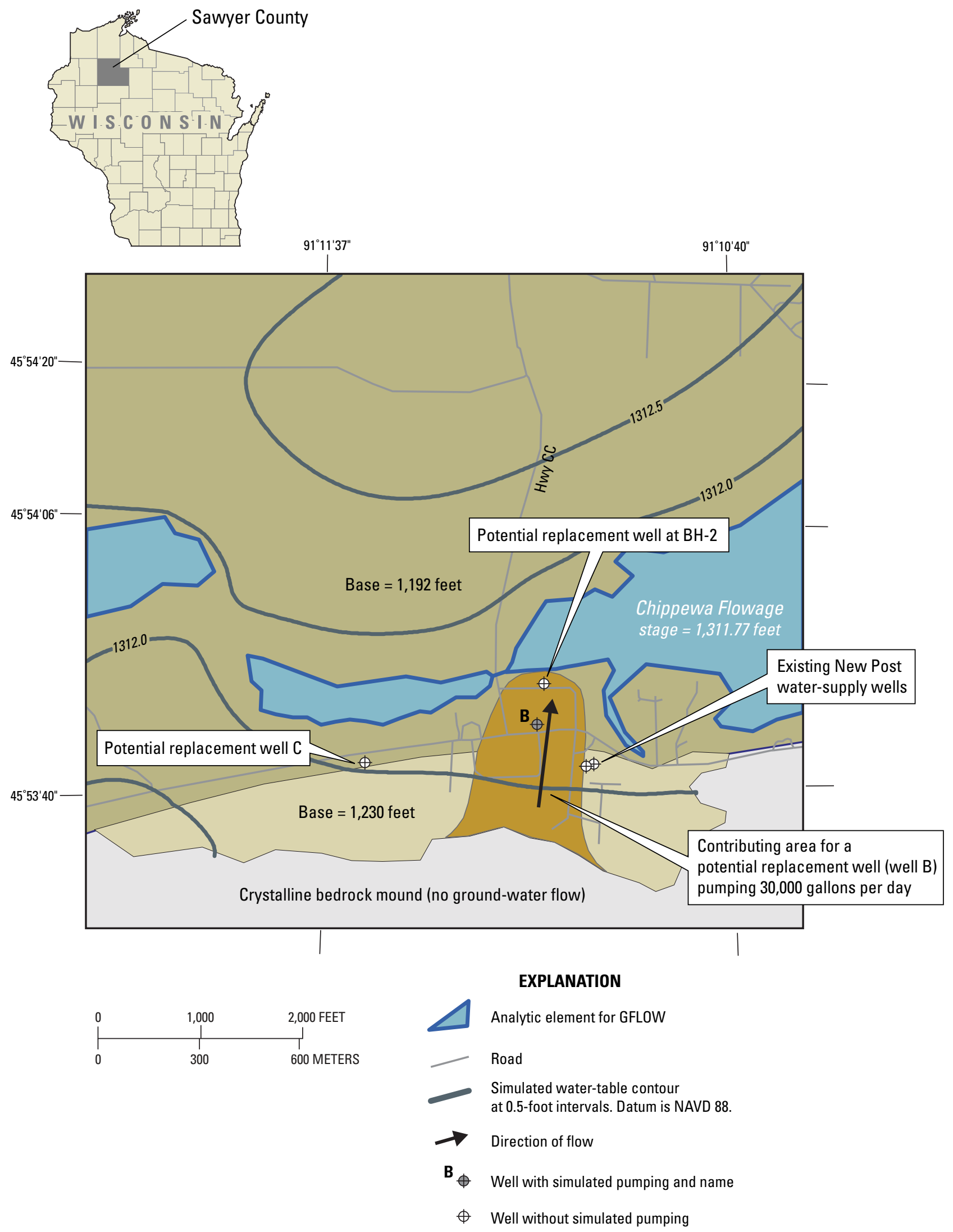

Figure 3. Simulated contributing area for potential replacement well B, pumping 30,000 gallons per day, with low resistance (0.005 day) to vertical flow along the Chippewa Flowage (scenario 3). 


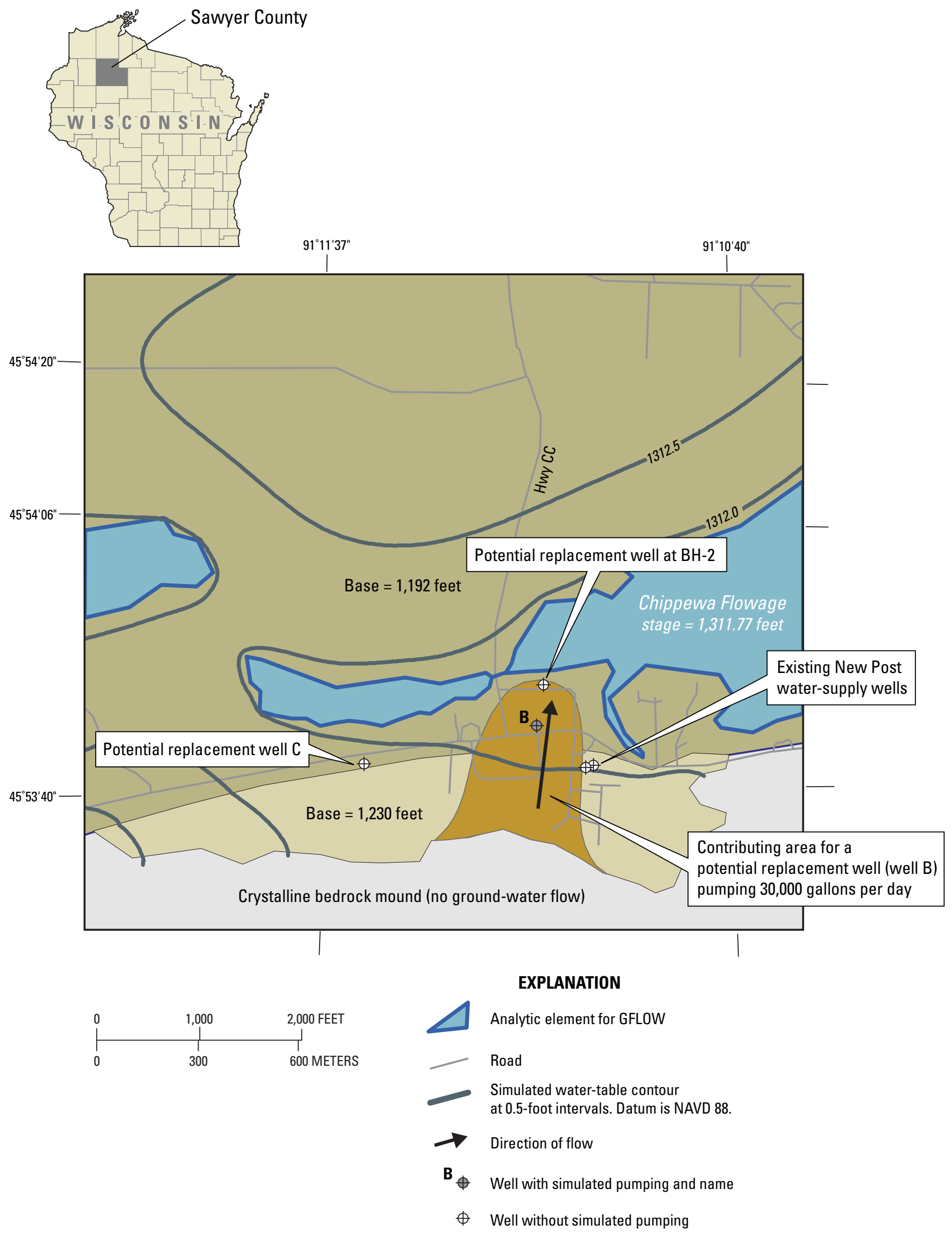

Figure 4. Simulated contributing area for potential replacement well B, pumping 30,000 gallons per day, with high resistance (5 days) to vertical flow along the Chippewa Flowage (scenario 4). 


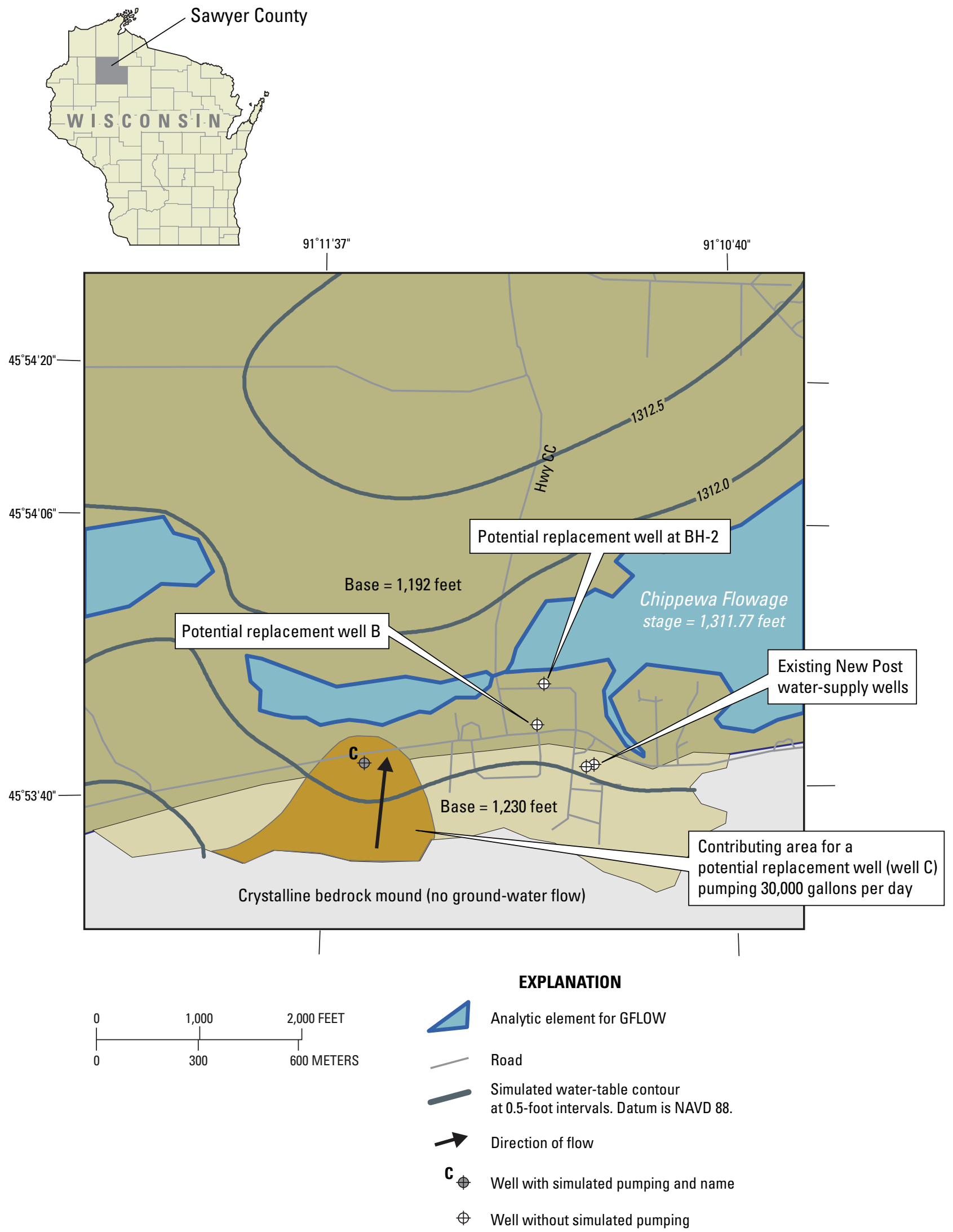

Figure 5. Simulated contributing area for potential replacement well C, pumping 30,000 gallons per day, with low resistance (0.005 day) to vertical flow along the Chippewa Flowage (scenario 5). 




Figure 6. Simulated contributing area for potential replacement well C, pumping 30,000 gallons per day, with high resistance $(5$ days) to vertical flow along the Chippewa Flowage (scenario 6). 


\section{Summary}

Six scenarios were simulated to evaluate contributing areas and surface-water leakage associated with pumping from three potential replacement well locations. For each well location, two cases were evaluated: one in which resistance to vertical flow was negligible and one in which resistance to vertical flow was substantial. Surface-water leakage ranged from 39 percent to less than 1 percent of total well pumping for a well at borehole BH-2 (scenarios 1 and 2), a location that is within $130 \mathrm{ft}$ of the Chippewa Flowage and sufficiently close for vertical flow to be important. The simulated contributing area extended from the Chippewa Flowage to a crystalline bedrock mound south of the community of New Post for both scenarios, but it also extended north of the flowage for the high-streambed-resistance scenario in which surface-water leakage represented less than 1 percent of well capture (scenario 2). For the remaining two potential well locations (scenarios 3 through 6), no surface-water leakage was simulated because of the increased distance from the Chippewa Flowage. In all scenarios, the simulated range in resistance to vertical flow was expected to provide reasonable bounds for surfacewater leakage - a range that compensates for the limitations associated with approximating three-dimensional flow near a surface-water feature with a two-dimensional model (primarily important in scenarios 1 and 2).

\section{References Cited}

Graczyk, D.J., Hunt, R.J., Greb, S.R., Buchwald, C.A., and Krohelski, J.T., 2003, Hydrology, nutrient concentrations, and nutrient yields in nearshore areas of four lakes in northern Wisconsin, 1999-2001: U.S. Geological Survey WaterResources Investigations Report 03-4144, 64 p.

Haitjema, H.M., 1995, Analytic element modeling of groundwater flow: San Diego, Calif., Academic Press, 394 p.
Haitjema, H.M., 2005, Dealing with resistance to flow into surface waters: Unpublished document, 9 p., accessed August 31, 2007, at http://www.haitjema.com/documents/De alingwithresistancetoflowintosurfacewaters.pdf

Haitjema, Henk, 2006. The role of hand calculations in ground water flow modeling: Ground Water, v. 44, no. 6 , p. 786-791.

Hunt, R.J., 2006, Ground water modeling applications using the analytic element method: Ground Water, v. 44, no. 1, p. $5-14$.

Hunt, R.J., Anderson, M.P., and Kelson, V.A., 1998, Improving a complex finite-difference ground water flow model through the use of an analytic element screening model: Ground Water, v. 36, no. 6, p. 1011-1017.

Hunt, R.J., Haitjema, H.M., Krohelski, J.T., and Feinstein, D.T., 2003, Simulating ground water-lake interactionsApproaches and insights: Ground Water, v. 41, no. 2, p. 227-237.

Hunt, R.J., and Krohelski, J.T., 1996, The application of an analytic element model to investigate groundwater-lake interactions at Pretty Lake, Wisconsin: Journal of Lake and Reservoir Management, v. 12, no. 4, p. 487-495.

Juckem, P.F., and Hunt, R.J., 2007, Simulation of the shallow ground-water-flow system near Grindstone Creek and the Community of New Post, Sawyer County, Wisconsin. U.S. Geological Survey Scientific Investigations Report 2007-5014, 29 p.

Kenoyer, G.J., 1988, Tracer test analysis of anisotropy in hydraulic conductivity of granular aquifers: Ground Water Monitoring Review, v. 8, no. 3, p. 67-70.

Tyrolt, D.D., 2006, New Post soil boring sieve analysis report: Unpublished document on file at the Lac Courte Oreilles Conservation Department, $21 \mathrm{p}$. 
12 Simulation of Contributing Areas and Surface-Water Leakage to Potential Replacement Wells, New Post, Wis. 

